\title{
粗粒材養浜時における磁浜上での砂層形成予測モデル

\author{
Model for Predicting Formation of Sand Layers on Gravel Beach \\ after Beach Nourishment using Coarse Materials
}

\author{
古谷真広 $^{1}$ ・ 小林昭男 ${ }^{2} \cdot$ 宇多高明 ${ }^{3}$. 野志保仁 ${ }^{4}$
}

\author{
Masahiro KOYA, Akio KOBAYASHI, Takaaki UDA and Yasuhito NOSHI
}

\begin{abstract}
Field observation on sand deposition on the gravel beach was carried out on the Jinkoji and Akashi coasts facing the Pacific Ocean. On the basis of the contour-line-change-model, a model for predicting sand deposition on the gravel beach under the calm wave conditions was developed, taking into consideration that the equilibrium slope of sand is increased due to the percolation effect of gravel bed and its effect depends on the thickness of sand layer. Furthermore, landward movement of gravel due to storm waves was explained by the model. Predicted results were in good agreement with measured values.
\end{abstract}

\section{1. はじめに}

茨城県の神向寺海岸では，径3〜13mmの礫を用いた 粗粒材養浜が行われ，これにより過去に消失した砂浜の 復元が可能なことが明らかにされた（松浦ら，2009）. 神向寺海岸での粗粒材養浜の成功を受けて, 神向寺海岸 の北に隣接する明石海岸でも2008年 11 月より同じ粒径 の碟による養浜が開始された。古谷ら（2010）は，明 石海岸の養浜後定点写真撮影を行い，これより静穏時に 鿬浜の表面に砂が堆積する一方，荒天時には砂層が消失 すると同時に碟が岸側へと打込まれることを明らかにし た。また，細砂中砂の平衡勾配を計算開始時から急勾配 で与える手法により縦断形変化のモデル化を図った。し かし, 実際には砂浜上に堆積する砂の平衡勾配は, 砂層 厚に応じて変わると考えられる．また，荒天時の砂層消 失と礫の打込みの計算も行われたが，静稳時に形成され た砂層を構成している土砂の空間的広がりと粒径含有
率，さらには埋没碟層の空間分布の予測はできていない. 本研究では, 野志ら（2009）のモデルを基礎として, これらを考慮した縦断形変化予測モデルを開発した。

\section{2. 碟浜に関する現地調査}

\section{（1）礫浜上への砂の堆積}

縦断形予測モデルの構築に先立ち, 神向寺海岸での粗 粒材養浜後の縦断形や砂層厚の変化を調べた古谷ら （2010）の結果に加え, 他の時期における海浜状況変化 の観察結果も加えて考察する。図-2 は, 図-1に示す神向 寺海岸の 7 号HLの南側隣接部における 2008 年 12 月 4 日と 2009 年 8 月 8 日における海浜状況の変化を示す. 投入粗 粒材は色が黒いことから, 図-2(a) では汀線からバーム まで全体に粗粒材が堆積していたことが分かる．海浜利 用面から見ると素足では歩きづらい状態にあった。しか し2009年 8月 8 日の調査では図-2（b）に示すように碟浜 上に砂が堆積して海浜の色が白くなり, 海浜利用面から

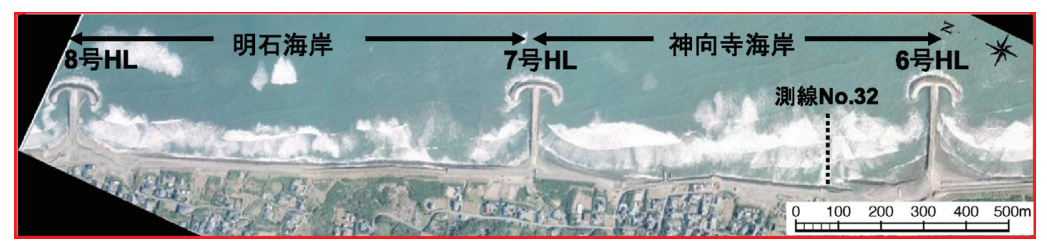

図-1 神向寺 - 明石海岸の位置と砂層調査の測線No.32の位置

\begin{tabular}{|c|c|c|}
\hline 1 & 修(工) & 栗田工業株式会社 \\
\hline 2 正会員 & 工博 & 日本大学教授理工学部海洋建築工学科 \\
\hline 3 正会員 & 工博 & $\begin{array}{l}\text { (財)土木研究センター常務理事なぎさ } \\
\text { 総合研究室長兼日本大学客員教授 } \\
\text { 理工学部海洋建築工学科 }\end{array}$ \\
\hline 正会員 & 博 (工) & (有)アイコム \\
\hline
\end{tabular}

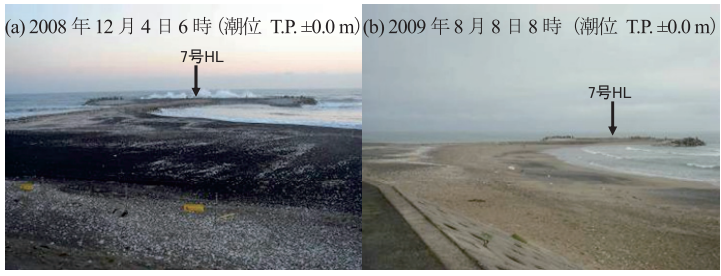

図-2 冬季と夏季の海浜状況の変化 (神向寺海岸の 7 号HLの南側隣接部) 


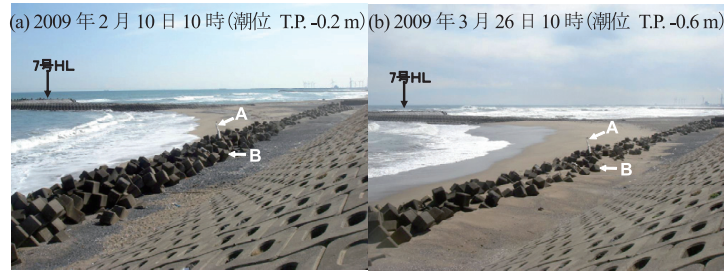

図-32009年2月 10 日と 2009年3月26日の海岸状況の変化 (古谷ら, 2010)



図-4 2009年2月 10 日～2009年3月 26 日の波浪条件

大きく改善されていた. とくに前浜の水際線に近い部分 では, 礫浜上への堆砂の層厚は最も薄い地点でも 20〜 $30 \mathrm{~cm}$, 厚い場所では $1 \mathrm{~m}$ 以上もあって, 礫床は完全に隠 されていた. 砂浜上への砂の堆積は夏季の比較的静穏な 波浪条件下で起きており, 砂浜での波浪の強弱に伴う沖 向き岸向きの漂砂と, 砂浜の持つ高い浸透性が関係して いることを示唆する。図-3は，2009年2月 10 日と 2009年 3 月26日の神向寺海岸の海浜状況の変化を示す（古谷ら, 2010）。2009年 2 月までに粗粒材養浜が行われ，緩傾斜護 岸ののり先と平行に設置されていた消波堤の半ばを埋め て砂が堆積していた．消波堤の海側では白く見えるよう に磁層の上に砂が堆積していたが, 消波堤の陸側はほと んどの区域が啋で覆われていた。しかし46日経過後の 2009年3月26日には消波堤の岸側に白い砂が堆積した。 黒い礫浜から白い砂浜への変化は，図-2に見られた変化 と全く同様である。図-3(a)，（b）において，消波堤に突 き刺さった流木を $\mathrm{A}$ ，その下部の異形ブロックを $\mathrm{B}$ とし て比較すると, 2 月 10 日にはBの頭が砂磻上に突き出て いたが3月26日には頭の部分を残してほぼ砂に埋まった ことから, 砂碟の上に岸向きに運ばれた砂が堆積し約 $0.4 \mathrm{~m}$ 地盤高が上昇したことが分かった。また消波堤沖に 大量の砂が堆積して前浜が広がると同時に, 消波堤の異 (a) 2009 年 8 月 8 日 12 時(潮位 T.P. $-0.6 \mathrm{~m}$ ) $\quad$ (b) 2009 年 9 月 1 日 10 時 (潮位 T.P. $-0.3 \mathrm{~m}$ )

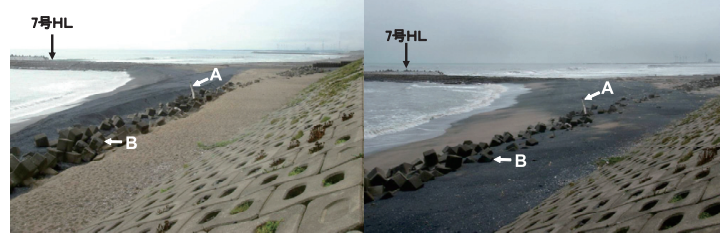

図-5 2009年8月 8 日〜 2009年9月 1 日の海岸状況の変化

形ブロック間から陸向きに何本もの筋目模様が見えるこ とから，ほぼ海岸線と直角方向に砂が運び込まれたこと が明らかであり，このような地形変化がHLより離れた 場所でも起きていることから, HLによる波の遮蔽域で の局所的現象ではなく, 2 次元海浜変形として起きたと 考えられる.

図-4は2009年2月 10 日〜 3 月 26 日の波浪条件の変化を 示す. 2 月 10 日から 3 月 3 日までの 21 日間, 日平均の $H_{1 / 3}$ は $1.31 \mathrm{~m}$ (平均波形勾配 0.016 ） と静穏な状態が続いた. したがってこの間には前浜での堆砂が進んだと考えられ るが，その直後の3月4日から 3 月 7 日には低気圧の通過 に伴って波高が高まり，3月6日には $H_{1 / 3}=3.01 \mathrm{~m}$ の高波浪 が来襲したことから，これ以前に前浜に堆積していた砂 は沖向きに運ばれたと考えられる。しかし3月8日から 3 月 24 日までの 16 日間再び静穏となり, $H_{1 / 3}$ は平均で $1.24 \mathrm{~m}$ （平均波形勾配 0.013）となったことから，2月 10 日から 3 月 3 日の静穏時と同様, 前浜への堆積が進んだ と考えられる.さらに 3 月 25 日には $H_{1 / 3}=2.21 \mathrm{~m}$ の高波が 作用したため，前日までに前浜に堆積した砂は再び沖向 きに運ばれた可能性はある。しかし 3 月3日から 3 月 8 日 までの期間では $H_{1 / 3}=2 \mathrm{~m}$ 以上の高波浪が 4 日間継続したの に対し，観測日直前の3月 25 日には最大波高が 3 月 6 日の $H_{1 / 3}=3.01 \mathrm{~m}$ と比べて $H_{1 / 3}=2.21 \mathrm{~m}$ と低く, かつ高波浪の継 続時間が 1 日と短かったため，3月 24 日までに生じた前 浜での堆積の影響が色濃く残されたと考えられる。結局, 2 月 10 日から 3 月 26 日までの間には堆積作用と侵食作用 がそれぞれ2回発生しており，3月26日の前浜地形には それらの作用の履歴効果が残されているものの, 観測日 直前における波の作用の結果が強く現れていると考えら れる.

\section{(2) 磁の岸向き移動}

粗粒材養浜におけるもう一つの特徵は, 高波浪の作用 時遡上高の高まりに応じて碟が陸側に打ち込まれること である。この現象も 2 回観察された。第 1 回は2009年 8 月 8 日〜9月 1 日に観察されたもので, 観測期間中に台風 11 号に伴う最大有義波高 $5.12 \mathrm{~m}$ （周期 $8.6 \mathrm{~s}$ ）の波の作用があ った。第 2 回は，2009年9月 17 日〜 10月 2 日の期間であ り, この間 $H_{1 / 3}=3.1 \mathrm{~m}$ の高波浪が作用した結果, 砂の岸向 き移動が起きた. 




図-6 2009年8月 8日〜2009年9月 1日の海岸状況の変化 （7号 HL上から北向きに望む）

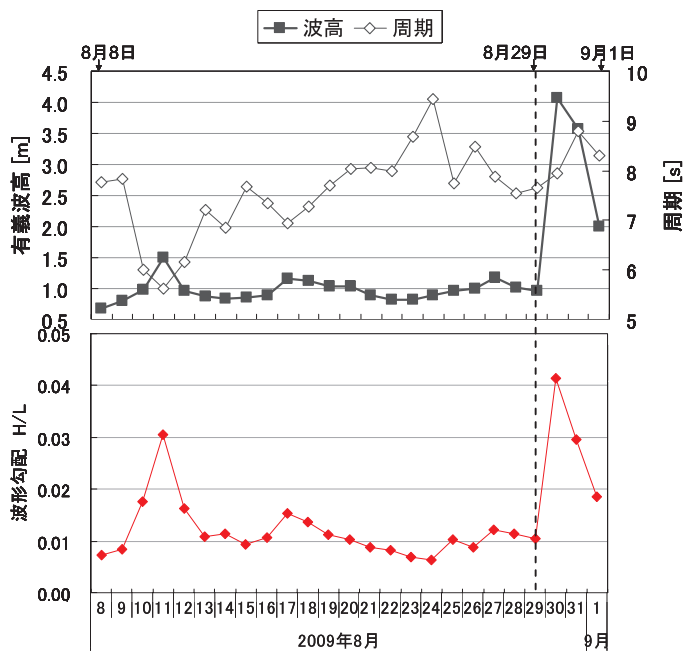

図-7 2009年8月 8 日～2009年9月 1 日の波浪条件

図-5 (a) は2009年 8 月 8 日の海浜状況を示す。この時 期は粗粒材の投入が行われていた時期であり，消波堤の 海側には鿬が敷き並べつつあったが，消波堤と緩傾斜護 岸の間は砂礫が堆積し，砂の色が白かった。しかし2009 年9月1日には図-5 (b) のように消波堤より陸側に大量の 粗粒材が打ち込まれ，海浜全体が黒くなった．異形ブロ ック B 付近での地盤高の上昇量は約 $0.7 \mathrm{~m}$ であった．定点 写真は，7号HL上から図-5 (a) の撮影位置方向を望んで も行われた。7号 HL上から 2009年 8 月 8 日と9月 1 日に北 向きに望んで撮影された写真が図-6 (a)，（b）である．8 月 8 日には粗粒材養浜により高いバームが形成されてい たが，9月1日にはバームを形成していた礫はほとんど全 部削り取られ，岸向きに移動したことが分かる。このよ うにいずれの方向から見ても磁が岸向きに運ばれたこと が明らかである。

図-7は，2009年8月 8日～9月 1 日における波浪条件を 示すが，観測開始21日目の8月29日までは平均の $\mathrm{H} 1 / 3$ が $0.97 \mathrm{~m}$ と静穏な状態が続いた。したがってこの間は砂の 堆積も起きたと推定されるが，8月30日には台風11号に より $H_{1 / 3}$ が最大で $5.12 \mathrm{~m}$ （周期 $8.6 \mathrm{~s}$ ） という高波浪が襲来 した。この結果，高波浪の作用により堆積していた砂は 沖向きに流出すると同時に，バームを形成して堆積して

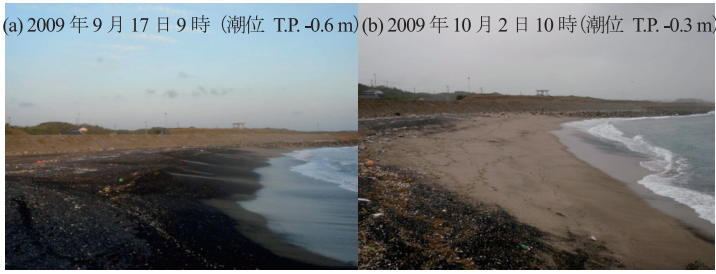

図-8 2009年9月17日〜2009年10月2日の海岸状況の変化 （7号 HL上から北向きに望む）

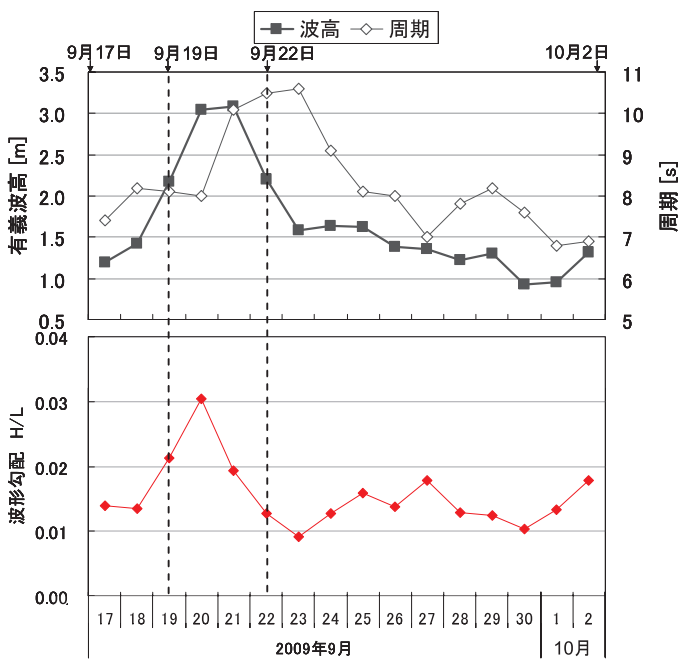

図-9 2009年9月17日〜2009年10月 2 日の波浪条件

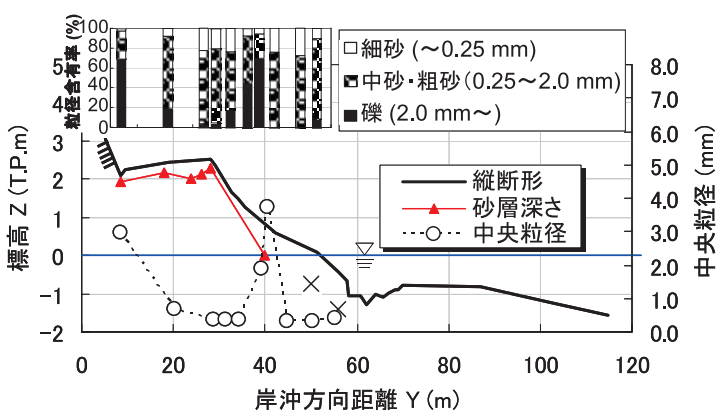

図-10 神向寺海岸の測線No.32における縦断形変化と砂層厚 分布

いた粗粒材は短時間で岸へと打ち上げられたと考えら れる。

第 2 回目の 2009 年 9 月 17 日〜 10 月 2 日の観察における, 図-6の撮影位置と同一地点から撮影した地形変化を図-8 （a）（b）に示す．9月17日には黒い礫が大量に堆積し高 いバームが形成されていたが，10月2日には磁バームは 消失し，偗は岸側へと打ち上げられた。しかし，その後 汀線付近での砂の堆積が進みつつある。図-9はこの期間 の波浪条件を示す，9月19日から22日まで4日間， $H_{1 / 3}$ は $2 \mathrm{~m}$ 以上の高波浪となり，とくに9月 21 日には $H_{1 / 3}=3.1 \mathrm{~m}$ の高波浪が襲来している。このことから，高いバームを 
表-1 計算条件

\begin{tabular}{|c|c|c|c|c|}
\hline \multicolumn{3}{|c|}{ 計算ケース } & \begin{tabular}{|c|}
1 \\
静穏時
\end{tabular} & \begin{tabular}{|c|}
2 \\
荒天時
\end{tabular} \\
\hline \multirow{3}{*}{\multicolumn{2}{|c|}{ 初期勾配 }} & $Z=5.0 \sim-0.5$ & $1 / 6$ & \\
\hline & & $Z=-1.0 \sim-5.0$ & $1 / 60$ & \\
\hline & & $Z=-5.5 \sim-10$ & $1 / 150$ & \\
\hline \multirow{6}{*}{ 初期粒径含有率 } & \multirow{3}{*}{$Z=5.0 \sim-0.5$} & 礫, $7.0 \mathrm{~mm}$ & $100 \%$ & \\
\hline & & 中砂, $0.425 \mathrm{~mm}$ & $0 \%$ & \\
\hline & & 細砂, $0.106 \mathrm{~mm}$ & $0 \%$ & \\
\hline & \multirow{3}{*}{$Z=-1.0 \sim-10$} & 礫, $7.0 \mathrm{~mm}$ & $0 \%$ & \\
\hline & & 中砂, $0.425 \mathrm{~mm}$ & $30 \%$ & \\
\hline & & 細砂, $0.106 \mathrm{~mm}$ & $70 \%$ & \\
\hline \multirow{3}{*}{\multicolumn{2}{|c|}{ 平衡勾配 }} & 礫, $7.0 \mathrm{~mm}$ & \multicolumn{2}{|c|}{$1 / 6$} \\
\hline & & 中砂, $0.425 \mathrm{~mm}$ & $1 / 30$ & $1 / 100$ \\
\hline & & 細砂, $0.106 \mathrm{~mm}$ & $1 / 100$ & $1 / 100$ \\
\hline \multirow{3}{*}{\multicolumn{2}{|c|}{$\begin{array}{c}\text { 浸透効果により } \\
\text { 急勾配化した平衡勾配 }\end{array}$}} & 礫, $7.0 \mathrm{~mm}$ & 7 & \\
\hline & & 中砂, $0.425 \mathrm{~mm}$ & $1 / 6$ & \\
\hline & & 細砂， $0.106 \mathrm{~mm}$ & \multirow{2}{*}{\multicolumn{2}{|c|}{$\frac{1 / 6 \quad}{0.5}$}} \\
\hline \multicolumn{3}{|c|}{ 交換層幅B（m) } & & \\
\hline \multirow{3}{*}{ 入射波条件 } & \multicolumn{2}{|c|}{ 砕波波高 $H_{b}(\mathrm{~m})$} & \multirow{2}{*}{\multicolumn{2}{|c|}{\begin{tabular}{c|c}
1.2 & 2.5 \\
0.0
\end{tabular}}} \\
\hline & \multicolumn{2}{|c|}{ 砕波波向 $\alpha_{b s}$ (deg.) } & & \\
\hline & \multicolumn{2}{|c|}{ 潮位条件M.S.L.（m） } & \multicolumn{2}{|c|}{0.0} \\
\hline \multirow{3}{*}{$\begin{array}{c}\text { 地形変化の } \\
\text { 水深範囲 } \\
\text { 漂砂量係数 }\end{array}$} & \multicolumn{2}{|c|}{ 地形変化の限界水深 $h_{C}(\mathrm{~m})$} & \multicolumn{2}{|c|}{\begin{tabular}{|l|l|}
6.0 & 8.0 \\
\end{tabular}} \\
\hline & \multicolumn{2}{|c|}{ バーム高 $h_{R}(\mathrm{~m})$} & 2.5 & 3.5 \\
\hline & \multicolumn{2}{|c|}{ 漂砂量係数 $A$} & \multicolumn{2}{|c|}{0.3} \\
\hline \multirow{2}{*}{$\begin{array}{c}\text { 土砂落ち込みの } \\
\text { 限界勾配 }\end{array}$} & \multirow{2}{*}{\multicolumn{2}{|c|}{$\begin{array}{l}\text { 陸域 } \\
\text { 海域 }\end{array}$}} & \multicolumn{2}{|c|}{$1 / 2$} \\
\hline & \multirow{2}{*}{\multicolumn{2}{|c|}{$\begin{array}{c}\text { 海垉 } \\
\text { 鉛直方向 } Z(\mathrm{~m})\end{array}$}} & \multicolumn{2}{|c|}{$1 / 3$} \\
\hline 計算範囲 & & & \multicolumn{2}{|c|}{$-10 \sim 5$} \\
\hline 計算メッシュ & \multicolumn{2}{|c|}{$\Delta Z(\mathrm{~m})$} & \multicolumn{2}{|c|}{0.5} \\
\hline \multirow{2}{*}{ 履歴メッシュ } & & ツシュ数R & & 0.0 \\
\hline & メッシ & 間隔 $\Delta X R(\mathrm{~m})$ & 0 & .5 \\
\hline & 計算時 & 間間隔 $\Delta t(\mathrm{hr})$ & $5.0 \times\left(10^{-4}\right)$ & $5.0 \times\left(10^{-6}\right)$ \\
\hline 計算ステップ & & ステップ数 & $5.0 \times\left(10^{5}\right)$ & $1.0 \times\left(10^{5}\right)$ \\
\hline & 時 & 換算 $(h r)$ & 250 & 5 \\
\hline
\end{tabular}

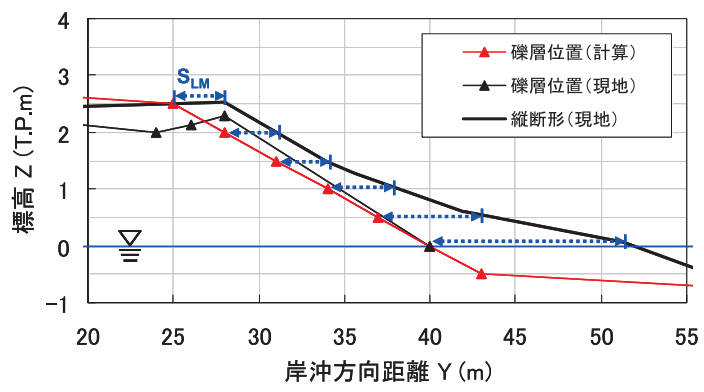

図-11 各標高の砂層厚とその閾值

形成していた磁はこのときの高波浪の作用で岸向きに打 ち込まれたが, 9 月 23 日〜 10月 2 日では $H_{1 / 3}$ が $1.5 \mathrm{~m}$ 以下 の静穏な状態が続いたことから, 汀線付近では再び砂の 堆積が起きたと考えられる．以上に示した土砂移動にお いては, 砂の堆積に要する時間が 2 週間程度かかるのに 対し, 高波浪時の砂の沖向き移動および磷の岸向き移動 は1 日程度で完結し, 応答時間が異なることも特徵のひ とつである。

図-10は神向寺海岸の測線No.32（図-1）での測量結果 と底質粒度組成を示す．海浜表面の砂層を鉛直方向に掘 削し, 地中の礫層に達した深さをム印で示した。×印は 掘削中に磉層に達する前に地下水位に達してしまったた め掘削を終えた深さである。ここで砂層厚はバーム頂部
の $Z=2.0 \mathrm{~m}$ で約 $0.3 \mathrm{~m}, Z=0.0 \mathrm{~m}$ で約 $0.8 \mathrm{~m}$ であった. また地 中の磼層勾配は $1 / 5$ であるのに対し, 砂層勾配はバーム

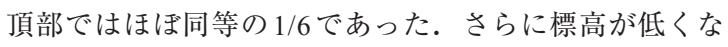
り汀線へ近づくほど勾配が緩く, 汀線付近の $Z=0.5 \mathrm{~m}$ での 勾配は $1 / 17$, 海面下の $Z=-1.0 \mathrm{~m}$ 以下では $1 / 45$ 勾配となっ た. 砂層厚と併せて見ると, 勾配が急なバーム頂部では 砂層厚が小さく, 逆に勾配が緩くなる汀線付近では砂層 厚は大きくなる特徵があるが，これらは前報では予測で きなかった，砂層の粒度組成は, 中砂粗砂が $80 \%$, 細砂 が $20 \%$ 程度を占める。

\section{3. 縦断形変化の予測モデル}

現地観測の結果によれば, 次の推定が可能である.ま ず，砂浜では浸透が顕著に見られたことから，浸透によ り戻り流れが弱まり, これに伴い砂の平衡勾配が急とな つて砂斜面上での砂層形成が可能になったと考えられ る. また, 地下水位との水頭差が最も大きく, 浸透効果 が著しいと考えられるバーム頂部では前浜勾配が急なの に対し, 鿬浜への浸透が弱まる汀線付近では海浜勾配が 緩くなったと推定される. 本研究では, これらの推定に 基づいてモデル化を進め, 礫床上に堆積する砂の平衡勾 配を砂層厚に応じて変化させた．ここで調查結果を参考 として, 各標高の砂層厚とその閾值を図-11に示すよう に $S_{L}, S_{L M}$ とし, 浸透効果が生じた場合の平衡勾配を式 （1）から算出した.

$$
\cot \beta_{c}=\left(\cot \beta_{0}-\cot \beta_{p}\right) \times \frac{S_{L}}{S_{L M}}+\cot \beta_{p}, \frac{S_{L}}{S_{L M}} \leq 1 \cdots \text { (1) }
$$

ここに， $\beta_{P}$ は浸透効果によって急勾配化した勾配角， $\beta_{0}$ は本来の平衡勾配である。礫層の勾配は約 $1 / 6$ であり, また沖合の勾配は約 1/65であることから，石井ら（2006） を参考に $Z=-0.5 \mathrm{~m}$ で折れた複断面を初期縦断形とした. 粒径含有率の初期值は, 沖浜底質の砂の含有率（細砂： 中砂 $=7: 3$ ）を与えた. 砂層厚は現地測量結果に基づき, 浸透効果が発揮されるであろう $Z=0 \mathrm{~m}$ 以上の標高毎に層 厚の閾值を設定し, ある標高における層厚が閾值を超え た場合, それより1つ上の標高の層厚を参照するものと した．これにより標高の低い礫斜面上から徐々に砂層が 形成されていく過程の再現が可能となる. そして砂斜面 上の各標高全ての層厚が閾值に達した場合, 浸透効果は 発揮されず砂の平衡勾配は本来のものに戻るものとし た. 古谷ら（2010）によれば, 砂層上での砂層形成は静 穏波条件で起きたことから, 沖の細砂中砂の平衡勾配は, 砂層が全くない場合は浸透効果により礫斜面の勾配と等 しいが, 砂層厚が厚くなると細砂中砂の有する平衡勾配 に漸近するとした。

一方, 高波浪作用時の縦断形変化については, 福濱ら 


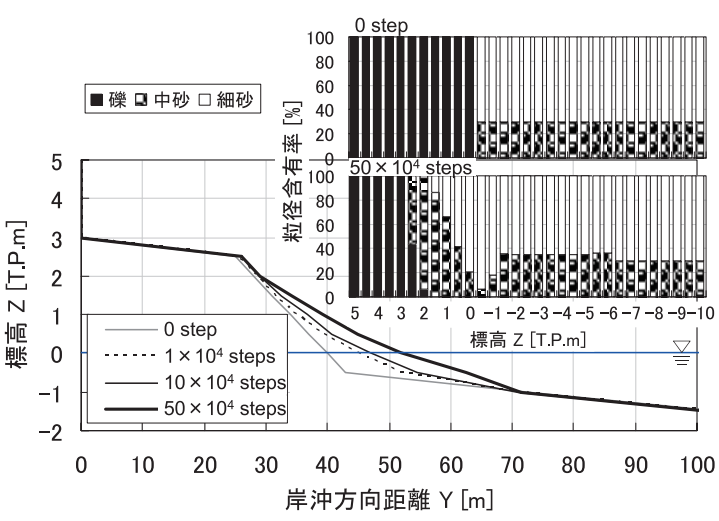

図-12 静穏時の砂層形成の再現計算結果



図-13静穏時の計算結果と測量結果の比較

（2008）を参考に砂の平衡勾配を減少させ，かつ高波浪 に伴い波の遡上高が増大するとし，バーム高を $2.5 \mathrm{~m}$ から $3.5 \mathrm{~m}$ に高めた. また, 荒天時には地下水位が上昇するこ とから，浸透効果による砂の平衡勾配の増大は起こらな いとし，一方で砂は急な平衡勾配を保ったままなので， 砂層は消失するが碩はより高い標高へ打込まれると考え た。このとき静穏時に記憶した堆積土砂の履歴を考慮す ることにより, 砂層を形成していた細砂中砂と, 埋没し た磻の土砂収支をそれぞれ満足させることが可能とな る。計算では，表-1に示すように静穏波の作用後に高波 浪を作用させた。

\section{4. 予測計算の結果}

静穏時における砂層形成の縦断形変化と，標高ごとに 整理した海浜表面の粒径含有率の分布を図-12に示す. 浸透効果により砂の持つ平衡勾配が急になることで碟斜 面上に砂層が形成され，砂層は緩やかな縦断形を持って 初期断面にすり付く分布となった。また，当初の汀線よ り陸側の海浜表面は礫のみで覆われていたが，波の作用 とともに砂上に中砂と細砂が載り $+2 \mathrm{~m}$ まで礫の含有率が 低下したことが分かる。実測縦断形と計算縦断形を図-13 に示すが，計算された砂層形状および汀線位置は両者で 良い一致を示している。図-14 は，高波浪時における碟 の打ち达みと砂の沖向き移動状況の計算結果として, 縦

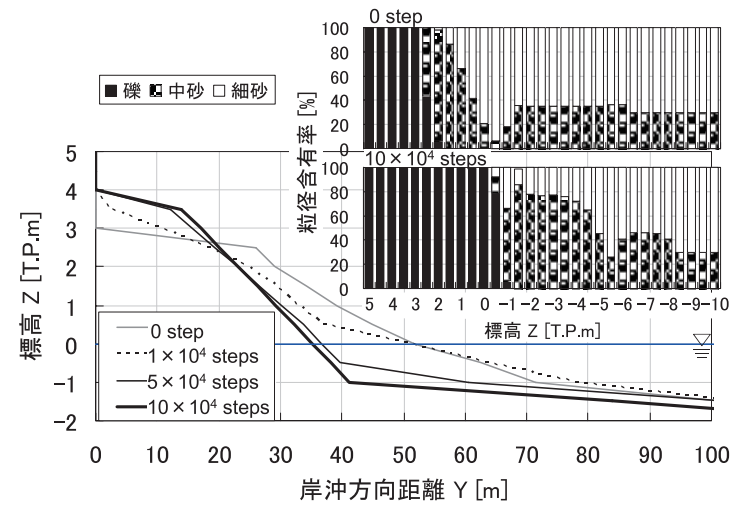

図-14 荒天時の礫打込みの再現計算結果

断形変化と，標高ごとに整理した海浜表面の粒径含有率 の分布を示す。高波浪の作用により護岸前面に䃇が集中 的に堆積して地盤高が上昇することが見て取れる。また， 当初礫は前浜のバーム直下の $+2 \mathrm{~m}$ 以上にのみ存在し, $+2 \mathrm{~m}$ 以下は中砂または細砂で覆われていたが，波の作用 により砂が沖へと運び去られた結果，ほぼ-1mまで碟が 現れた。このように高波浪時に磁が護岸前面へとうちあ げられる状況は図-5の観察結果をうまく説明している.

\section{5. まとめ}

野志ら（2009）のモデルを基礎として，静穏波条件で の碟浜への堆砂について礫浜の浸透効果により砂の平衡 勾配が砂層厚に応じて変わると考えてモデルを図った。 また，荒天時の砂層消失と磁の打込みの計算のモデル化 も行った。このモデルに実測勾配を与えて計算したとこ ろ，静穏時に形成された砂層を構成している土砂の空間 分布と粒径含有率，さらに埋没碟層の空間分布をある程 度まで計算できた。このことから，少なくとも観察に基 づいたモデル化が実現象をかなりうまく表現していると 考えられる。

\section{参 考 文 献}

石井秀雄 - 中村友和 - 宇多高明 - 大木康弘 - 熊田貴之 ·芹沢 真澄（2006）：茨城県神向寺海岸での粗粒材養浜による砂 浜の安定化，海洋開発論文集，第22巻，pp.887-892.

古谷真広 - 小林昭男 ·宇多高明 - 野志保仁 (2010) : 明石海岸 における礫養浜後の海浜状況変化, 海洋開発論文集, 第 26 巻, pp.1053-1057.

野志保仁 - 小林昭男 - 宇多高明 - 芹沢真澄 · 熊田貴之 (2009)：滑らかな縦断形を予測可能な3次元モデルを利用 した養浜効果検討, 海岸工学論文集, 第 56 巻, pp.691695 .

福濱方哉 ·宇多高明 - 山田浩次 · 芹沢真澄 - 石川仁憲 （2008）：前浜勾配と汀線の短期変動の予測モデル，海洋 開発論文集，第24巻，pp.1237-1242.

松浦健郎 ·宇多高明 · 諏訪義雄 · 山田浩次 · 福本崇嗣 （2009）：砂浜の海岸保全施設指定に向けた粗粒材養浜の 有効性の検討，海洋開発論文集，第25巻，pp.1119-1124. 